\title{
Lessons From Zika Policies to Improve Gender Equity
}

\author{
Emma Richardson ${ }^{1,2}$, Elizabeth Alvarez ${ }^{2,3^{*}}$, Temitayo Ifafore-Calfee ${ }^{4}$ \\ ${ }^{1}$ Centre for Ethical, Social and Cultural Risk, St. Michael's Hospital, Toronto, Canada \\ ${ }^{2}$ Department of Health Research Methods, Evidence and Impact, McMaster University, Hamilton, Canada \\ ${ }^{3}$ Centre for Health Economics and Policy Analysis (CHEPA), McMaster University, Hamilton, Canada \\ ${ }^{4}$ Global South Solutions, Arlington, USA
}

Corresponding Author: Elizabeth Alvarez, MD, MPH, PhD, Assistant Professor, Department of Health Research Methods, Evidence and Impact, McMaster University, CRL 2nd Floor, 1280 Main Street West, Hamilton ON L8S 4K1, Canada.

Tel: +1-905-515-8401, Email: alvare@mcmaster.ca

Received June 21, 2018; Accepted September 11, 2018; Online Published November 19, 2018

\begin{abstract}
Gender equity is easily supported in theory but harder to pursue in practice. In this article, the case of Zika travel policies is used to illustrate some glaring gaps related to gender, for both men and women, at both international and national levels. Zika travel policies have not considered new evidence on biological or social determinants of health, putting babies at risk of exposure. The authors suggest best practices at the international level, such as developing pre-organized gender committees to provide actionable and swift advice for international infectious disease policies; at the national level, such as promoting holistic policies addressing mosquito control and sex and gender considerations, including access to reproductive health services; and at the local level, such as education on local infectious diseases. These deliberations are especially important with emerging infectious diseases (EIDs), as little may be known about them. New knowledge needs to be translated in a timely fashion in order to shape effective and equitable policies.

Keywords: Zika Virus, Gender Identity, Sex, Health Equity, Global Health, Policy
\end{abstract}

Citation: Richardson E, Alvarez E, Ifafore-Calfee T. Lessons from Zika policies to improve gender equity. Int J Travel Med Glob Health. 2018;6(4):139140. doi:10.15171/ijtmgh.2018.25.

\section{Introduction}

Gender equity is easy to support in theory but harder to consistently and effectively pursue in practice. The arena of global health policy is no exception, and the urgent nature of emerging infectious diseases (EIDs) makes thinking about gender equity in advance and thoroughly, before the next big emergency, all the more important. Herein, the case of Zika travel policies is used to illustrate some glaring gaps related to gender, for both men and women, and to suggest best practices.

Zika exploded on the global scene when it was designated a "Public Health Emergency of International Concern," on February 1, 2016. International organizations almost immediately advised women who were pregnant, or trying to become pregnant, to avoid travel to areas known to have Zika, such as most countries in Latin America. ${ }^{2}$ It has already been pointed out how these policies would inadvertently reduce international women's input on a whole generation of global health projects. ${ }^{3}$ Even more intriguing from a gender equity lens is that, even after Zika was identified as a sexually transmitted infection, ${ }^{4}$ travel policies were never updated to advise men planning to procreate from avoiding travel to
Zika-endemic regions. Why is it that, in a partnership of a man and a woman trying to get pregnant, when either one could expose the fetus to Zika, only the woman was advised to stay at home?

\section{International, National and Local Considerations}

The inconsistency in this Zika travel policy not only minimized the risk to men and their babies, but also was coercive for women. Interestingly, prior to the Rio Olympics in the same summer of 2016, high profile male golfers made headlines by declining to travel to Brazil, citing a fear of contracting Zika in relation to their intentions to start a family. ${ }^{5}$ Others took matters in their own hands and decided to freeze sperm ahead of time. ${ }^{5}$ These actions, however, were seemingly individual responses to the information that Zika, while contractible through mosquito bites, was also transmissible through sex with one's partner. Why these pieces were not considered more coherently and transparently in World Health Organization (WHO) policy remains to be understood.

During the recent Zika epidemic, several Latin and South American countries advised women to delay pregnancy. However, in their contexts, this recommendation ignored

Copyright $\odot 2018$ The Author(s). This is an open-access article distributed under the terms of the Creative Commons Attribution License (http:// creativecommons.org/licenses/by/4.0), which permits unrestricted use, distribution, and reproduction in any medium, provided the original work is properly cited. 
gender power imbalances, the lack of reproductive rights, the lack of access to contraception and abortion, and, yet again, placed blame and responsibility on the woman, while it is well understood that both men and women share in procreation. As Harris et al stated, "While recommendations to avoid pregnancy make sense as a Zika infection management strategy, these recommendations become senseless and unjust in contexts where access to reliable contraception is not guaranteed."6 A welcome exception to this was women's groups in Brazil, which promoted a holistic policy towards Zika, including mosquito control, but also access to sexual education, contraceptives, prenatal care, and the option of safe and legal abortion. ${ }^{7}$ Another recommendation is to have local public health agencies inform travelers at the port of entry of the risks and methods to minimize risks for locally acquired infectious diseases. ${ }^{8}$ Having international and national processes in place for evidence-informed decisionmaking will make local education more effective.

As we look to preparing for the next emerging infectious disease, we applaud country commitments to better respond to future EIDs under the Global Health Security Agenda. ${ }^{9}$ However, gender considerations are noticeably missing from country action packages. In 2011, the WHO recommended that sex and gender be taken into account as part of a comprehensive infectious disease response program. ${ }^{10}$ To achieve this laudable yet clearly elusive goal, the authors suggest pre-organized gender committees who provide actionable and swift advice for international infectious disease policies as they are being developed.

\section{Conclusion}

The biological and social determinants of health need to be considered in policies related to EIDs. New knowledge needs to be translated in a timely fashion in order to shape effective and equitable policies. The authors suggest best practices at the international level, such as developing pre-organized gender committees to provide actionable and swift advice for international infectious disease policies; at the national level, such as promoting holistic policies addressing mosquito control and sex and gender considerations, including access to reproductive health services; and at the local level, through education on local infectious diseases.

\section{Authors' Contributions}

All authors contributed equally to this article.

\section{Conflict of Interest Disclosures}

The authors declare that they have no conflicts of interest.

\section{Ethical Approval}

Not applicable.

\section{Funding/Support}

None.

\section{References}

1. World Health Organization (WHO). WHO statement on the first meeting of the International Health Regulations (2005) (IHR 2005) Emergency Committee on Zika virus and observed increase in neurological disorders and neonatal malformations. WHO website. http://www.who.int/mediacentre/news/statements/2016/1stemergency-committee-zika/en/. Updated February 1, 2016. Accessed February 27, 2018.

2. Hafner J. Women advised to avoid pregnancy as Zika virus spreads. USA Today. 2016. https://www.usatoday.com/story/news/ nation-now/2016/01/25/womenasked-avoid-pregnancy-zikavirus-spreads/79305676/. Accessed February 27, 2018.

3. Richardson E. Zika travel policies may reduce women's leadership in global health. Glob Health Sci Pract. 2016;4(4):696-697. doi:10.9745/ghsp-d-16-00282.

4. Wiwanitkit V. Safe travel during the period of emerging Zika virus infection. Int J Travel Med Glob Health. 2016;4(4):100. doi:10.21859/ijtmgh-040401.

5. Dunlap T. Everything You Need to Know About the Athletes Skipping the Rio Olympics - and How Participants Are Addressing Zika Fears. People website. http://people.com/sports/rio-2016all-the-athletes-skipping-the-olympics-addressing-zika-fears/. Accessed February 28, 2018. Published 2016.

6. Harris LH, Silverman NS, Marshall MF. The paradigm of the paradox: women, pregnant women, and the unequal burdens of the Zika virus pandemic. Am J Bioeth. 2016;16(5):1-4. doi:10.108 0/15265161.2016.1177367.

7. Slattery E. Brazil Can Fight the Zika Virus with Better Public Policy. Open Society Foundation website. https://www. opensocietyfoundations.org/voices/brazil-can-fight-zika-virusbetter-public-policy. Accessed February 27, 2018. Published 2016.

8. Wiwanitkit $\mathrm{V}$. Zika virus infection after returning from Thailand. Int J Travel Med Glob Health. 2016;4(2):69. doi:10.20286/ ijtmgh-04027.

9. Advancing the Global Health Security Agenda: Progress and Early Impact from U.S. Investment. Global Health Security Agenda; 2016. https://www.ghsagenda.org/docs/default-source/defaultdocument-library/ghsa-legacy-report.pdf. Accessed February 27, 2018.

10. World Health Organization (WHO). Taking sex and gender into account in emerging infectious disease programmes: an analytical framework. World Health Organization website. http://www.wpro. who.int/topics/gender_issues/Takingsexandgenderintoaccount. pdf?ua=1\&ua=1. Accessed February 27, 2018. Published 2011. 